\title{
Synthesis and Characterization of Egg Shell (ES) and Egg Shell with Membrane (ESM) Modified by Ionic Liquids
}

\author{
Boumediene Haddad $^{1,2,3}$, Alok Mittal ${ }^{*}$, Jyoti Mittal ${ }^{4}$, Annalisa Paolone ${ }^{5}$, Didier Villemin ${ }^{3}$, Debdab Mansour \\ ${ }^{6}$, Mimanne Goussem ${ }^{7}$, Habibi Asmaa ${ }^{1}$, Hamidi Zineb ${ }^{1}$, Mostefa Boumediene ${ }^{1,2}$, El-habib Belarbi ${ }^{6}$ \\ ${ }^{1}$ Department of Chemistry, DrMoulayTahar University of Saida, Saida, Algeria \\ ${ }^{2}$ Chemistry Laboratory of Synthesis, Properties, and Applications (CLSPA-Saida), University of Saida, Algeria. \\ ${ }^{3}$ LCMT, ENSICAEN, UMR 6507 CNRS, University of Caen, 6 bd Ml Juin, 14050 Caen, France \\ ${ }^{4}$ Department of Chemistry, Maulana Azad National Institute of Technology, Bhopal 462 003, India \\ ${ }^{5}$ CNR-ISC, U.O.S. La Sapienza, Piazzale A. Moro 5, 00185 Roma, Italy \\ ${ }^{6}$ Synthesis and Catalysis Laboratory LSCT, Tiaret University, Tiaret, Algeria \\ ${ }^{7}$ Université DjillaliLiabes, BP 89, 22000 Sidi-Bel-Abbes, Algeria \\ *Corresponding author E- mail: (aljymittal@gmail.com).
}

\begin{abstract}
Egg shell (ES) is a biological macromolecule mainly containing calcite embedded in proteins and polysaccharides, while shell membrane predominantly contains proteins. Thus ES with membrane (ESM) possesses richer protein contents than ES. In the present work, ES and ESM have been separately modified using mono- and di- cationic imidazolium ionic liquids, $\left[\mathrm{C}_{5} \mathrm{mim}^{+}\right]\left[\mathrm{Br}^{-}\right]$(IL) and [Bis-( $\left.\left.\mathrm{PhCH}_{2} \mathrm{MIm}\right)^{+}\right]\left[2 \mathrm{Cl}^{-}\right]$(DIL). Thus four modified products have been obtained namely ES-IL, ESDIL, ESM-IL and ESM-DIL. In order to determine physico-chemical modifications of the ES due to the interactions with the ionic liquids, the structural, spectroscopic and thermal properties of all products were investigated by means of XRD, FTIR and TG/DTA. The IR spectra display significant changes in the $1400-1550$ and $2800-3100 \mathrm{~cm}^{-1}$ regions confirming the insertion of IL and DIL into the ES and ESM layers. Furthermore, the XRD results indicate that this modification process influence the crystal structure of the ES. Thermal analysis suggests that the chemical modification increases the thermal stability of the ES and ESM. It has also been ascertained that presence of proteins in the shell membrane is responsible for increasing thermal stability in the order ES $<$ ESM $<$ ES-IL $<$ ESM-IL $<$ ES-DIL $<$ ESM-DIL.
\end{abstract}

Keywords: ionic liquids, egg shells, egg shells with membrane, protein, thermal stability. 


\section{Graphical Abstract}

Ionic Liquids

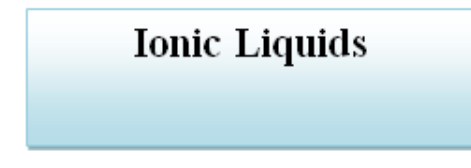

Egg Shells and Egg Shells with Membrane

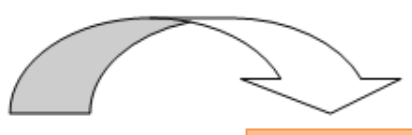

First Report of Chemical Modification

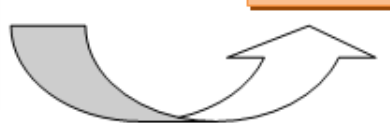

Structural

Spectroscopic

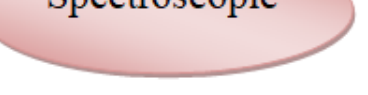

Thermal

\section{Specifications Table}

\begin{tabular}{|c|c|}
\hline Subject area & Materials Science \\
\hline Compounds & $\begin{array}{l}\text { 1-methyl-3-pentylimidazolium bromide, 4,4'-bis-(3-methylimidazolium-1-yl- } \\
\text { methyl) biphenyl dichloride }\end{array}$ \\
\hline Data & $\begin{array}{l}\text { Structural modification of biological products Egg Shell and Egg Shell } \\
\text { Membrane using monocationic }\left[\mathrm{C}_{5} \mathrm{MIm}^{+}\right]\left[\mathrm{Br}^{-}\right] \text {(IL) and dicationic [Bis- } \\
\left.\left(\mathrm{PhCH}_{2} \mathrm{MIm}\right)^{+}\right]\left[2 \mathrm{Cl}^{-}\right] \text {(DIL) ionic liquids to synthesize their four modified } \\
\text { products. }\end{array}$ \\
\hline $\begin{array}{l}\text { Data acquisition } \\
\text { format }\end{array}$ & NMR analysis, XRD patterns, IR spectra, Thermal analysis curves, TGA curves \\
\hline Data type & Analysed and graphical data \\
\hline Procedure & $\begin{array}{l}\text { Known quantities of eggshells and eggshell membranes were taken in two } \\
\text { different beakers each having } 100 \mathrm{ml} \text { of distilled water. Both the beakers were } \\
\text { mixed with ionic liquid monocationic }\left[\mathrm{C}_{5} \mathrm{MIm}^{+}\right]\left[\mathrm{Br}^{-}\right] \text {and methanol. In other two } \\
\text { beakers eggshells and eggshell membranes were mixed with dicationic [Bis- } \\
\left.\left.\text { ( } \mathrm{PhCH}_{2} \mathrm{MIm}\right)^{+}\right]\left[2 \mathrm{Cl}^{-}\right] \text {ionic liquids along with methanol. All the solutions were } \\
\text { thoroughly stirred at medium speed and room temperature. Modified products } \\
\text { thus obtained in each beaker were filtered, washed, dried and finally granulated. }\end{array}$ \\
\hline Dat & $\begin{array}{l}\text { A detailed spectroscopic analysis of both types of synthesized ionic liquids (IL } \\
\text { and DIL) was carried out by }{ }^{1} \mathrm{H} \text { and }{ }^{13} \mathrm{C} \text {-NMR spectroscopy. Also, the physical } \\
\text { and chemical characterizations of all the six prepared products were made by } \\
\text { using XRD patterns, IR spectra and TGA /DTA measurements. }\end{array}$ \\
\hline
\end{tabular}




\section{Rationale}

The chicken egg is one of the most consumed products in the world [1]. Poultries, food manufacturing units, homes and restaurants produce large amount of chicken egg waste on daily basis. Egg Shell (ES) is a hard outer cover of the egg which protects the albumen fluid of the egg. It is a waste product which is generated in large quantity on daily basis. The inner wall of the ES is covered with a membrane, which is a semi permeable clear film. ES is porous in nature and contains large amount of $\mathrm{CaCO}_{3}$ embedded within polysaccharides and proteins, while eggshell membrane (ESM) mainly contains fibrous proteins [2-3]. The anatomy of ES reveals the presence of layered ceramic materials which are strengthened due to presence of protein, while ESM additionally contain long linear polysaccharides, commonly known as glycosaminoglycans or mucopoly saccharides, along with proteins $[4-5]$.

Due to porous and membrane like properties, both ES and ESM attracted considerable attention to effectively utilize these waste materials as potential adsorbents for the removal of some hazardous chemicals. The past decade has witnessed publication of several research papers and review articles on the utilization of ES and several toxic dyes and metal ions have been proficiently removed from waters and wastewaters by using this material [ $6-10]$. Numerous previous studies have also indicated that the thermal, morphological and textural properties of ES strongly depend upon its elemental composition and its high adsorption ability is due the available pores [11 - 16].

In recent years, modifications of existing materials have been extensively carried out to develop a variety of new products with better chemical and physical properties $[17,18]$. For example, surface modification using ionic liquids is an eco-friendly process to generate an adsorbent with better scavenging properties $[19-21]$. Reports are available where imidazolium based ionic liquids have been used as modifier for different adsorbents and the developed materials are found to possess improved pore sizes, thermal stability and adsorption capability [22 - 23]. In recent years, the imidazole ionic liquids with different functional groups have been chemically modified and used as supported ionic liquids phases (SILPs). These materials have successfully employed as de-acidifies to crude oils [24] and mercury adsorption from a gas stream [25]. To the best of our knowledge, the modification of biological products as ES and ESM using ionic liquids have not been carried out so far and neither the evidences are available in the literature regarding their preparation nor about their structural, spectroscopic and thermal properties. Hence, the aims of this work is a novel attempt to structurally modify ES and ESM using monocationic $\left[\mathrm{C}_{5} \mathrm{MIm}^{+}\right]\left[\mathrm{Br}^{-}\right]$(IL) or dicationic [Bis$\left.\left(\mathrm{PhCH}_{2} \mathrm{MIm}\right)^{+}\right]\left[2 \mathrm{Cl}^{-}\right]$(DIL) ionic liquids and to synthesize their four modified products, henceforth 
called ES-IL, ES-DIL, ESM-IL and ESM-DIL. This paper includes synthesis procedures of of all the six above mentioned materials and studies on their structural, spectroscopic and thermal properties.

\section{Procedure}

ES were collected from a restaurant of University campus of Sidi Bel Abbes in western Algeria. After cleaning all the waste ES with running gentle stream of water, samples were rinsed several times with deionized water. To get egg shells without the membranes (ES), the membranes were manually stripped from the inner walls of the washed ES, and the products were again washed and dried in an oven. The remaining ES were directly dried in the oven and called egg shell with membrane (ESM). The dried eggshells, with or without membranes, were ground separately in an agate mortar and the obtained fine powders particles were sieved to $200 \mu \mathrm{m}$. Finally, the calcinations process was performed at $600^{\circ} \mathrm{C}$ for $60 \mathrm{~min}$ (with a heating rate of $10^{\circ} \mathrm{C} / \mathrm{min}$ ) and the products were kept in vacuum desiccator until use.

High purity chemicals 1-methylimidazole, [4,4'- bis (chloromethyl)-1,1'- biphenyl] and pentyl bromide (97\%) were purchased from M/s Fluka and used as received. Deionized $\mathrm{H}_{2} \mathrm{O}$ was obtained with a Millipore ion-exchange resin deionizer. Solvents used in synthesis, purification and NMR characterization (N,N-dimethylformamide and diethyl ether) were also procured from M/s Fluka. $\mathrm{CDCl}_{3}$ and deuterated dimethyl sulfoxide (DMSO- $d_{6}$ ) were obtained from M/s Aldrich.

\subsection{Preparation of monocationic IL and dicationic DIL}

Both ionic liquids, IL and DIL, were synthesized (Scheme 1) from the 1-methylimidazole precursor according to reported procedures [26, 27]. The first ionic liquid, IL with IUPAC name 1methyl-3-pentylimidazolium bromide, was prepared under microwave exposure by the chemical reaction of 1-methylimidazole and pentyl bromide for $5 \mathrm{~min}$ at $110^{\circ} \mathrm{C}$. The reaction mixture was evaporated at reduced pressure and the product thus obtained was washed repeatedly with diethyl ether $(5 \times 20 \mathrm{~mL})$ to remove any excess pentyl bromide. Then the product was dried under vacuum for $8 \mathrm{~h}$ to obtain a product with high purity. A viscous slightly yellowish liquid with 93\% yield was obtained.

The second ionic liquid, DIL with IUPAC name 4,4'-bis-(3-methylimidazolium-1-yl-methyl) biphenyl dichloride [Bis- $\left.\left(\mathrm{PhCH}_{2} \mathrm{MIm}\right)^{+}\right]\left[2 \mathrm{Cl}^{-}\right]$, was also prepared under microwave irradiation. $3.28 \mathrm{~g}$ $(3.18 \mathrm{ml}, 40 \mathrm{mmol})$ of 1-methylimidazole was mixed with $5.02 \mathrm{~g}(20 \mathrm{mmol})$ of the [4,4'-bis (chloromethyl) -1,1'- biphenyl] in $\mathrm{N}, \mathrm{N}$ - dimethylformamide $(3 \mathrm{ml})$ at $100{ }^{\circ} \mathrm{C}$ for $3 \mathrm{~min}$. The resulting crude precipitate was collected by filtration and washed three times upon addition of diethyl ether (100 $\mathrm{ml}$ ) to remove any unreacted reactants, and then it was dried under high vacuum for $8 \mathrm{~h}$, to obtain a white hygroscopic solid of high yield $(\approx 97 \%)$. 
Furthermore, in order to obtain high purity, both IL and DIL were dried under vacuum $\left(10^{-3}\right.$ bar) with phosphorus pentoxide for $72 \mathrm{~h}$ to remove any possible water contamination before their use. The water content was kept below 280 ppm. This measure was carried out by coulometric Karl Fischer titration, performed by a Metrohm 831.

\subsection{Chemical modification of ES and ESM}

In a beaker, $100 \mathrm{ml}$ of distilled water was added into a mixture of IL $(0.5752 \mathrm{~g})$ and ES (2.5133g), while in another beaker DIL (0.2957 g) was mixed with ES (1.4029 g) by taking the same volume of distilled water. In each beaker $20 \mathrm{~mL}$ methanol was added and the solutions were stirred at medium speed and room temperature. After 24 hours of thorough mixing, the ES in both beakers were found to be modified by IL and DIL, respectively. Thus ES-IL and ES-DIL precipitates were separated by filtration, washed several times with distilled water, dried in a convection oven at $60^{\circ} \mathrm{C}$ during $24 \mathrm{~h}$ and finally crushed in a mortar. The obtained materials were kept in a vacuum desiccator until use. The same protocols were followed to prepare both ESM-IL and ESM-DIL.

\section{Instrumentation}

The structure and purity of both synthesized ionic liquids, IL and DIL, were confirmed by NMR analysis. ${ }^{1} \mathrm{H}-\mathrm{NMR}(500 \mathrm{MHz})$ and ${ }^{13} \mathrm{C}-\mathrm{NMR}(125.75 \mathrm{MHz})$ spectra were recorded by means of a Bruker DRX $400 \mathrm{MHz}$ spectrometer. Spectra were recorded in (DMSO-d $)$ and $\left(\mathrm{CDCl}_{3}\right)$, using the DMSO residual peak as the ${ }^{1} \mathrm{H}$ internal reference $(\delta=2.5$ and 3.3), and the central peak of DMSO-d 6 at $\delta=39.5$ as the ${ }^{13} \mathrm{C}$ reference. Chemical shifts $(\delta)$ are given in ppm and referred to the internal solvent signal, namely TMS and $\mathrm{CFCl}_{3}$, respectively.

The structures of IL, DIL, ES-IL and ES-DIL, ESM-IL and ESM-DIL were characterized by Fourier transform infrared spectroscopy (FT-IR) performed by a Perkin-Elmer Spectrum BX spectrophotometer with a resolution of $4 \mathrm{~cm}^{-1}$ in the range $4000-650 \mathrm{~cm}^{-1}$.X-ray diffraction (XRD) patterns were collected on a Philips X-Pert diffractometer using $\mathrm{Ni}$ filtered $\mathrm{Cu} \mathrm{K} \alpha$ radiation $(\lambda$ $=1.54056 \AA$ ) in the $2 \theta$ range $2-80^{\circ}$ with a step size of $0.02^{\circ}$ at room temperature. All measurements of thermo-gravimetry (TGA) and differential thermal analysis (DTA) were performed by means of an apparatus model SetaramSetSys Evolution 1200, with a fixed temperature rate of $5^{\circ} \mathrm{C} / \mathrm{min}$, in an argon flux of $60 \mathrm{ml} / \mathrm{min}$. An initial mass of $\sim 30 \mathrm{mg}$ was used for each sample measurement.

\subsection{NMR characterization}

The structures of IL and DIL are confirmed by using ${ }^{1} \mathrm{H},{ }^{13} \mathrm{C}-\mathrm{NMR}$ spectroscopy and ascertain the absence of any impurities, e.g. residuals of the reactants or by-products. The synthesizing process and NMR spectroscopic data are given in Table 1.

\subsection{XRD characterization}


Figure 1 shows the XRD pattern of ES and ESM before and after the modification by IL and DIL ionic liquids. Firstly, the peaks are identified by comparing them with the Joint Committee on Powder Diffraction Standards (JCPDS) files and others similar works [28 - 32]. All patterns before and after modifications show many fine and quite intense peaks. At the first look, the compared XRD pattern of ES, ESM eggshells are quite similar, except for a little difference related to the intensity of the peaks that could be related to the presence of the membrane associated with shell.

\subsection{Infrared analysis}

In order to obtain a clear idea on the structural changes, first FTIR analysis of IL and DIL alone was performed, and their spectra are shown in Figure 2 and spectrum of DIL was found richer in modes as compared to IL.Similarly spectra of ES and ESM alone were measured at room temperature in the IR absorbance range 500 to $4000 \mathrm{~cm}^{-1}$ andpresented in Figures 3. Spectra recorded after modification of ES and ESM by IL and DILare exhibited in Figure. 4.

\subsection{Thermal analysis}

In order to study the effect of thermal behaviours of ES and ESM modified by IL and DIL, TGA and DTA measurements were carried out. The obtained resulting thermograms and heat flux curves are presented in Figures 5 to 7. Upon heating, the TGA curves of IL and DIL show that their decomposition start at $240{ }^{\circ} \mathrm{C}$ and in the temperature range $350-480{ }^{\circ} \mathrm{C}$ complete decomposition occurs, depending on their structures.

\section{Data, Value and Validation}

\subsection{XRD characterization}

Figure 1 indicates that in both ES and ESM, strong peaks appearing at $2 \theta=29.40^{\circ}$ and $37.38^{\circ}$, are the characteristic peaks of the calcite $\left(\mathrm{CaCO}_{3}\right)$ phase, while those appearing at $2 \theta=32.18^{\circ}, 39.32^{\circ}$, $43.14^{\circ}, 47.10^{\circ}, 48.46^{\circ}, 53.84^{\circ}, 57.38^{\circ}, 64.30^{\circ}$ and $67.36^{\circ}$ correspond to calcium oxide (CaO) [30]. These results confirm the presence of calcite and calcium oxide as the main constituents in the ES powder $[33,34]$. The peaks visible at $2 \theta=17.94,26.46^{\circ}, 34.18$ and $50.90^{\circ}$ are the characteristic peaks of calcium hydroxide $\mathrm{Ca}(\mathrm{OH})_{2}[29-31]$. These peaks are more intense in ESM due to the presence of $\mathrm{OH}$ group, suggesting that the ESM has moisture adsorption capability. Indeed, the appearance of $\mathrm{Ca}(\mathrm{OH})_{2}$ may be due to the exposure of $\mathrm{CaO}$ to atmospheric air [32]. Niju et al. [29] obtained similar peaks for calcined ES and Rivera et al. [35] obtained similar peaks for calcium oxide derived from ES.

By comparing the XRD results of ES and ESM with the respective IL/DIL modified products, the appearance of a new peak at $71.70^{\circ}$ and the disappearance of a peak at $37.41^{\circ}$ can be observed in the case of IL/DIL modified ES. On the other hand, the disappearance of two peaks at $37.41^{\circ}$ and $67.42^{\circ}$ and the appearance of a new peak at $32.16^{\circ}$ are observed for IL/DIL modified ESM. 
Upon close inspection, it is noted that diffraction peaks of ES and ESM still exist in ES modified with IL/DIL and ESM. However, it must be noted that the increase of the intensity of the peaks located at $2 \theta=29.40^{\circ}, 34.18^{\circ}, 47.10^{\circ}$ indicates a partial dissolution of $\mathrm{CaO}$ in water and the formation $\mathrm{Ca}(\mathrm{OH})_{2}$ as final product [29-32].

\subsection{IR characterization}

In the Figure 2, spectral zone $500-600 \mathrm{~cm}^{-1}$, the IR bands observed at 558, 625, 655, 758, and $848 \mathrm{~cm}^{-1}$ in the IL spectrum are assigned to the $\mathrm{C}-\mathrm{C}$ vibrations of the pentyl chain [36], while, the bands at $567,626,669,706,749,772,803$ and $826 \mathrm{~cm}^{-1}$ correspond to the $\mathrm{C}-\mathrm{C}$ deformation vibrations of the phenyl ring and methylene groups of the DIL. The $\mathrm{C}-\mathrm{H}$ bending vibrations and $\mathrm{C}-\mathrm{N}$ stretching modes present in $\left(\mathrm{N}-\mathrm{CH}_{2}\right)$ and $\left(\mathrm{N}-\mathrm{CH}_{3}\right)$ are observed at 1169 in the IL spectrum, and at 1166 in the DIL spectrum. On the other hand, bands appearing at $1335,1380 \mathrm{~cm}^{-1}$ in the IL spectrum and at 1319 , $1339,1361 \mathrm{~cm}^{-1}$ in the DIL spectrum are attributed both to the vibration $(\mathrm{C}-\mathrm{C})$ and to the stretching vibration $(\mathrm{C}-\mathrm{N})$ [37, 38].

Figure 2 also explains that the vibration bands with wavenumbers in the range of 1400-1700 $\mathrm{cm}^{-1}$ represent mainly the $\mathrm{C}=\mathrm{C}$, and $\mathrm{C}=\mathrm{N}$ bond stretching within the imidazole ring and phenyl ring modes [39]. The bands at around 1466, 1571, 1633 and $1673 \mathrm{~cm}^{-1}$ in IL spectrum can be assigned to the $\mathrm{C}=\mathrm{C}$ and $\mathrm{C}=\mathrm{N}$ stretching vibrations of the imidazolium cation of IL. Also, the bands at 1407, 1503 1574, 1627 and $1660 \mathrm{~cm}^{-1}$ in the DIL spectrum can be assigned to the same mode of $\mathrm{C}=\mathrm{C}$ and $\mathrm{C}=\mathrm{N}$ stretching vibrations of the imidazolium cation and the $\mathrm{C}=\mathrm{C}$ vibration of the aromatic phenyl ring. The IR bands observed at 2858, 2932 and $2956 \mathrm{~cm}^{-1}$ in the IL spectrum are assigned to $\mathrm{C}-\mathrm{H}$ stretching in the aliphatic pentyl chain [40, 41]. The bands at the highest frequency, 3065 and $3139 \mathrm{~cm}^{-1}$ for IL are assigned to the symmetric stretching modes of $\mathrm{C} 2-\mathrm{H}$ and $\mathrm{C} 4 / 5$ positions of the imidazole ring [42]. The methylene group and the aromatic $\mathrm{C}-\mathrm{H}$ modes of the phenyl ring are observed in the region 2863, $2930 \mathrm{~cm}^{-1}$ in the DIL spectrum, respectively. Moreover, the high wavenumber modes at 3033, 3082 and $3140 \mathrm{~cm}^{-1}$ can be assigned to stretching vibrations of imidazole ring in the DIL spectrum [43].

With the help of Figure 3 a similar behaviour in both spectra can be observed. The absorption bands occurring at $714,873,1047 / 1060$ and $1410 / 1418 \mathrm{~cm}^{-1}$ can be attributed to the vibrations of the carbonate $\mathrm{CO}_{3}{ }^{-2}$ anions $[31,34]$. Moreover, the weak IR peaks at2359 and $2514 \mathrm{~cm}^{-1}$ indicate the presence of organic matter in the ES spectrum; these modes are more intense in the case of the ESM spectrum. The bands located at 3420, 3725 and $3835 \mathrm{~cm}^{-1}$ in the ESM spectrum and at 3391, 3731 and $3863 \mathrm{~cm}^{-1}$ in ES have been attributed to H-bonded water due to humidity [44], while the sharp peak at $3640 \mathrm{~cm}^{-1}$ is due to the stretching vibration of hydroxyl groups attached to calcium oxide. These observations are in good agreement with the XRD characterization that shows the presence of $\mathrm{Ca}(\mathrm{OH})_{2}$ in both ES and ESM. 
Figure 4 presents graphs showing IR spectra of ES and ESM after modification by IL and DIL. These spectra exhibited similar bands in the region $400-1300$ and $3300-4000 \mathrm{~cm}^{-1}$ related to the structure of ES and ESM. IR spectra of modified ES and ESM indicate the occurrence of the IL and DIL functionalities. The small peaks in the region $1400-1550 \mathrm{~cm}^{-1}$ with a varying intensity were characteristic of the asymmetric bending vibrations of the methylene $-\mathrm{CH}_{2}-$ in the case of DIL and methyl $\mathrm{CH}_{3}$ groups of the pentyl chains in the case of IL [40 - 42]. In addition, the $\mathrm{C}=\mathrm{C}$ vibrational frequencies are the significant characteristic bands in the vibrational spectra of ES and ESM modified by IL and DIL. These new peaks appearing at $1593 \mathrm{~cm}^{-1}$ can be attributed to the stretching of the $\mathrm{C}=\mathrm{C}$ vibrations of phenyl and imidazolium rings. A pentyl chain in IL and phenyl groups gives significantly stronger peaks in the ranges of 2800-3100 cm$~^{-1}$. A very weak peaks near between 2900 and $3200 \mathrm{~cm}^{-1}$ can be observed in the spectra of the imidazolium modified ES and ESM. These new observed peaks confirmed the insertion of IL and DIL into the ES. The presence of the characteristic bands of IL and DIL in the IR spectra of the ES and ESM highlight the efficiency of the proposed process.

\subsection{Thermal analysis}

Interestingly, at room temperature the monocationic IL is liquid, while the DIL is solid and the melting temperature of DIL $\left[\mathrm{Bis}-\left(\mathrm{PhCH}_{2} \mathrm{MIm}\right)^{+}\right]\left[2 \mathrm{Cl}^{-}\right]$is higher than the boiling temperature of the IL $\left[\mathrm{C}_{5} \mathrm{mim}^{+}\right]\left[\mathrm{Br}^{-}\right][35]$. The fact that the DIL starts decomposing before the IL can be explained by its higher size and molecular structure $[45,46]$, knowing that $\left[\mathrm{Bis}-\left(\mathrm{PhCH}_{2} \mathrm{MIm}\right)^{+}\right]$has a bulkier cation, as compared to $\left[\mathrm{C}_{5} \mathrm{mim}^{+}\right]$, a saturated alkyl chains [39, 43].It is also significant that the anionic part (chloride or bromide) does not have any significant influence on the degradation temperature of IL and DIL. With the help of Figure 5 it can be observed that the thermal stability of the DIL is lower than that of the IL and the TGA curve of DIL exhibits a multistep degradation.

The TGA curves of ES, ESM and their IL/DIL modified products are reported in the temperature range $25-900{ }^{\circ} \mathrm{C}$ (Figure 6). For all the substances two stages of weight losses are observed. For ES, a total $18.75 \%$ weight loss was observed starting from $366^{\circ} \mathrm{C}$ up to $438^{\circ} \mathrm{C}$, while in the case of ESM the loss started from $389^{\circ} \mathrm{C}$, was completed at $445^{\circ} \mathrm{C}$ and only a $4 \%$ loss was recorded. This initial step of weight loss is originated from the decomposition of the organic matter, i.e. proteins, in ESM as compared to ES. This is in agreement with studies carried out by Mittal et al., which suggested that the carbonates, sulphates and phosphates of calcium, magnesium and organic matter are the major constituents of the ES, while ESM contains organic protein materials in addition [6]. Figure 6 also confirms that the chemical modification by ionic liquids IL and DIL increases the thermal stability of the ES. The second step of weight loss between 550 and $875^{\circ} \mathrm{C}$, is attributed to the decomposition of calcium carbonate. In this stem weight loss started at $646{ }^{\circ} \mathrm{C}$ and completed at 737 
${ }^{\circ} \mathrm{C}$ for ES and from $670{ }^{\circ} \mathrm{C}$ to $767{ }^{\circ} \mathrm{C}$ for ESM. Kaewtatip et al. [47], reported that weight losses of ES and ESM of this step are attributed to the release of $\mathrm{CO}_{2}$ to give $\mathrm{CaO}$.

In the similar manner TGA curves ES and ESM were recoded before and after modification by IL and DIL and presented in Figure 6. The difference in values of weight losses observed in the first step of the decomposition of both ES and ESM with IL and DIL is due to the introduction of IL and DIL inside the layered ES and ESM (Figure 6). The higher weight loss in the case of ESM-DIL is due to the presence of larger amount of DIL into the layered structures of ESM.

The DTA curves of ES, ESM and their modified products are recorded in the same temperature range and presented in Figure 7. For each sample, two endothermic peaks are visible, the first endothermic peaks at $422^{\circ} \mathrm{C}$ for ES and at $428{ }^{\circ} \mathrm{C}$ ESM corresponding to decomposition of their organic matter, while, the peaks at $437^{\circ} \mathrm{C}$ for ES-IL and $446^{\circ} \mathrm{C} \mathrm{ESM-IL} \mathrm{and} \mathrm{at} 452^{\circ} \mathrm{C}$ for ES-DIL and $455^{\circ} \mathrm{C}$ for ESM-DIL are associated to the thermal decomposition of organic spaces of the ES and ESM and decomposition of IL and DIL. The second stage is associated with the thermal decarbonation of calcium carbonate in all samples. This clearly indicates the DTA analysis is consistent with the TGA results.

Thus from these thermo-grams and depending on modified egg shell by IL or DIL ionic liquid type, it can be safely interpreted that the thermal stability of these materials follow the order $\mathrm{ES}<\mathrm{ESM}<\mathrm{ES}-\mathrm{IL}<\mathrm{ESM}-\mathrm{IL}<\mathrm{ES}-\mathrm{DIL}<\mathrm{ESM}-\mathrm{DIL}$. On the basis of obtained results it can be safely interpreted that both IL and DIL produce effective, eco-friendly and more thermally stable modified products of ES and ESM, which can be used for a variety of applications for example water treatment.

\section{Acknowledgements}

One of the authors (HB) is gratefully to the financial support provided by The Ministry of Higher Education and Scientific Research (MESRS) of Government of Algeria under PRFU project (B00L01UN200120180002). Authors (AM) and (JM) are thankful to Ministry of Human Resource

Development, Government of India for funding SPARC project (SPARC/2018-2019/P307/SL). Author JM is also thankful to MANIT, Bhopal for seed money project. Author (JM) is also thankful to MANIT, Bhopal for providing financial assistance under seed money grants project.

\section{Declaration of interests}

The authors declare that they have no known competing financial interests or personal relationships that could have appeared to influence the work reported in this paper. 


\section{References}

1. Egg as food - Wikipedia (accessed 25 December 2020).

2. F.S. Murakami, P.O. Rodrigues, C.M.T. de Campos, M.A.S. Silva, Physicochemical study of CaCO3 from egg shells, Food Science and Technology 27(3) (2007) 658-662. https://doi.org/10.1590/s0101-20612007000300035

3. J. Gautron, M. Bain, S. Solomon, Y. Nys, Soluble matrix of hen's eggshell extracts changes in vitro the rate of calcium carbonate precipitation and crystal morphology, British Poultry Science 37 (1996) 853-866. https://doi.org/10.1080/00071669608417914

4. S.E. Solomon, The eggshell: strength, structure and function, British Poultry Science, 51(1) (2010) 52-59. https://doi.org/10.1080/00071668.2010.497296

5. K. Lokaewmanee, K.E. Yamauchi, T. Komori, K. Saito, Eggshell quality, eggshell structure and small intestinal histology in laying hens fed dietary Pantoea- $6 \bowtie$ and plant extracts, Italian Journal of Animal Science, 13(2) (2014) 332-339. https://doi.org/10.4081/ijas.2014.3163

6. A. Mittal, M. Teotia, R.K. Soni, J. Mittal, Applications of egg shell and egg shell membrane as adsorbent: a review, Journal of Molecular Liquids, 223 (2016) 376-387. http://dx.doi.org/10.1016/j.molliq.2016.08.065

7. M. Ikram, A.U. Rehman, S. Ali, S. Ali, S.U.H. Bakhtiar, S. Alam, The adsorptive potential of chicken egg shells for the removal of oxalic acid from wastewater, Journal of Environmental Sciences 2(2) (2016) 118-131. http://dx.doi.org/10.5430/jbei.v2n2p118

8. H. Daraei, A. Mittal, M. Noorisepehr, J. Mittal, Separation of chromium from water samples using egg shell powder as a low-cost sorbent: kinetic and thermodynamic studies, Desalination and Water Treatment 53(1) (2015) 214-220. http://dx.doi.org/10.1080/19443994.2013.837011

9. H. Daraei, A. Mittal J. Mittal, H. Kamali, Optimization of $\mathrm{Cr}(\mathrm{VI})$ removal onto biosorbent eggshell membrane: experimental \& theoretical approaches, Desalination and Water Treatment 52(7-9) (2014) 1307-1315. http://dx.doi.org/10.1080/19443994.2013.787374

10. H. Daraei, A. Mittal, M. Noorisepehr, F. Daraei, Kinetic and equilibrium studies of adsorptive removal of phenol onto eggshell waste, Environmental Science and Pollution Research 20 (2013) 4603-4611. http://dx.doi.org/10.1007/s11356-012-1409-8

11. W. Chen, B. Li, C. Xu, L. Wang, Chemiluminescence flow biosensor for hydrogen peroxide using DNAzyme immobilized on eggshell membrane as a thermally stable biocatalyst, $\begin{array}{llll}\text { Biosensors and } & \text { 24(8) }\end{array}$ http://dx.doi.org/10.1016/j.bios.2009.01.010

12. J.M. Garcia-Ruiz, A.R. Navarro, O. Kalin, Textural analysis of eggshells, Materials Science and Engineering: C 3(2) (1995) 95-100. http://dx.doi.org/10.1016/0928-4931(95)00107-7

13. S. Lunge, D. Thakre, S. Kamble, N. Labhsetwar, S. Rayalu, Alumina supported carbon composite material with exceptionally high defluoridation property from eggshell waste, $\begin{array}{lllll}\text { Journal of Hazardous } & \text { Materials } 237 \text { (2012) }\end{array}$ http://dx.doi.org/10.1016/j.jhazmat.2012.08.023

14. W.T. Tsai, J.M. Yang, C.W. Lai, Y.H. Cheng, C.C. Lin, C.W. Yeh, Characterization and adsorption properties of eggshells and eggshell membrane, Bioresource Technology 97(3) (2006) 488-493. http://dx.doi.org/10.1016/j.biortech.2005.02.050

15. Y. Qiu, J. Chen, J. Zhang, Effect of calcination temperature on properties of eggshell Ni/MgO$\mathrm{Al}_{2} \mathrm{O}_{3}$ catalyst for partial oxidation of methane to syngas, Catalysis Letters 127(3-4) (2009) 312-318. https://doi.org/10.1007/s10562-008-9680-5

16. P.S. Guru, S. Dash, Eggshell particles (ESP) as potential adsorbent for styryl pyridinium dyes - a kinetic and thermodynamic study, Journal of Dispersion Science and Technology 33(7) (2012) 1012-1020. http://dx.doi.org/10.1080/01932691.2011.590750

17. J. Pinson, D. Thiry, Surface Modification of Polymers: Methods and Applications, Wiley, 2019. 
18. V. Mittal, Surface modification of layered silicates. II. Factors affecting thermal stability, $\begin{array}{llll}\text { Philosophical Magazine } & \text { 92(36) } & \text { (2012) } & \end{array}$ http://dx.doi.org/10.1080/14786435.2012.714497

19. A. Vazquez, M. Lopez, G. Kortaberria, L. Martín, I. Mondragon, Modification of montmorillonite with cationic surfactants. Thermal and chemical analysis including CEC determination, Applied Clay Science 41(1-2) (2008) 24-36. http://dx.doi.org/10.1016/j.clay.2007.10.001

20. M. Sprynskyy, T. Kowalkowski, H. Tutu, E.M. Cukrowska, B. Buszewski, Ionic liquid modified diatomite as a new effective adsorbent for uranium ions removal from aqueous solution, Colloids and Surfaces A: Physicochemical and Engineering Aspects 465 (2015) 159167. http://dx.doi.org/10.1016/j.colsurfa.2014.10.042

21. S. Mahmoudian, M.U. Wahit, A.F. Ismail, A.A. Yussuf, Preparation of regenerated cellulose/montmorillonite nanocomposite films via ionic liquids, Carbohydrate Polymers 88(4) (2012) 1251-1257. http://dx.doi.org/10.1016/j.carbpol.2012.01.088

22. F.G. Torres, O.P. Troncoso, F. Piaggio, A. Hijar, Structure-property relationships of a biopolymer network: the eggshell membrane, Acta Biomaterialia 6(9) (2010) 3687-3693. http://dx.doi.org/10.1016/j.actbio.2010.03.014

23. N. Li, L.N. Niu, Y.P. Qi, C.K.Y. Yiu, H. Ryou, D.D. Arola, J.H. Chen, D.H. Pashley, F.R. Tay, Subtleties of biomineralisation revealed by manipulation of the eggshell membrane, Biomaterials 32(34) (2011) 8743-8752. http://dx.doi.org/10.1016/j.biomaterials.2011.08.007

24. S.N. Shah, M. Pranesh, J.J. Raj, M.I.A. Mutalib, K.C. Lethesh, O.B. Ghanem, Z. Ullah, Deacidification of crude oil using supported ionic liquids phases, Separation and Purification Technology 196 (2018) 96-105. http://dx.doi.org/10.1016/j.seppur.2017.08.056

25. T. Abbas, L.K. Chellappan, M.IA. Mutalib, K.Y. Cheun, S.N. Shah, S. Nazir, A. Hassan, M.B. Abai, E. Khan, Stability and Performance of Physically Immobilized Ionic Liquids for Mercury Adsorption from a Gas Stream, Industrial\&Engineering Chemistry Research, 54(48) (2015) 12114-12123. http://dx.doi.org/10.1021/acs.iecr.5b01738

26. S.K. Panja, H. Boumediene, M. Drai, D. Villemin, S. Bresson, Probing effect of weak Hbonding on conformational change in ionic liquid: Experimental and DFT studies, Journal of Molecular Liquids 266 (2018) 727-732. http://dx.doi.org/10.1016/j.molliq.2018.07.007

27. B. Haddad, A. Paolone, M. Drai, M. Boumediene, D. Villemin, E.H. Belarbi, M. Rahmouni, S. Bresson, O. Abbas, Para-xylyl linked bis-imidazolium ionic liquids: a study of the conformers of the cation and of the anion-cation hydrogen bonding, Journal of Molecular Structure 1175 (2019) 175-184. http://dx.doi.org/10.1016/j.molstruc.2018.07.096

28. L. Mardiana, B. Ardiansah, R. Bakri, A.H. Cahyana, Y. Anita, N.P. Aziza, Utilization of eggshell-derived material as a solid base catalyst for efficient synthesis of substituted chalcones, Jurnal Teknologi, 79(5) (2017) 175-182. https://doi.org/10.11113/jt.v79.10220

29. S. Niju, K.M.M.S. Begum, N. Anantharaman, Preparation of biodiesel from waste frying oil using a green and renewable solid catalyst derived from egg shell, Environmental Progress \& Sustainable Energy 34(1) (2015) 248-254. https://doi.org/10.1002/ep.11939

30. A.K. Pradhan, P.K. Sahoo, Synthesis and study of thermal, mechanical and biodegradation properties of chitosan-g-PMMA with chicken egg shell (nano-CaO) as a novel bio-filler, Materials Science and Engineering: C80 (2017) 149-155. http://dx.doi.org/10.1016/j.msec.2017.04.076

31. B. Engin, H. Demirtas, M. Eken, Temperature effects on egg shells investigated by XRD, IR and ESR techniques, Radiation Physics and Chemistry 75(2) (2006) 268-277. http://dx.doi.org/10.1016/j.radphyschem.2005.09.013

32. S.R. Khan, S. Jamil, M.R.S.A. Janjua, Radiation assisted synthesis of dumb bell shaped calcium hydroxide nanostructures from egg shells and study of its thermal and catalytic 
applications, Chemical Physics Letters $710 \quad$ (2018) 45-53. https://doi.org/10.1016/j.cplett.2018.08.067

33. M. Verziu, S.M. Coman, R. Richards, V.I. Parvulescu, Transesterification of vegetable oils over $\mathrm{CaO}$ catalysts, Catalysis Today 167(1) (2011) 64-70. https://doi.org/10.1016/j.cattod.2010.12.031

34. Y. Eswararao, S. Niju, K.M.M.S. Begum, N. Anantharaman, S.M. Raj, Transesterification of jatropha oil using a mixture of natural shells as solid catalyst, Biofuels 7(4) (2016) 345-351. http://dx.doi.org/10.1080/17597269.2015.1138036

35. E.M. Rivera, M. Araiza, W. Brostow, V.M. Castano, J.R. Diaz-Estrada, R. Hernández, J.R. Rodriguez, Synthesis of hydroxyapatite from eggshells, Materials Letters 41(3) (1999) 128134. http://dx.doi.org/10.1016/s0167-577x(99)00118-4

36. B. Haddad, D. Mokhtar, M. Goussem, E.H. Belarbi, D. Villemin, S. Bresson, M. Rahmouni, N.R. Dhumal, H.J. Kim, J. Kiefer, Influence of methyl and propyl groups on the vibrational spectra of two imidazolium ionic liquids and their non-ionic precursors, Journal of Molecular Structure 1134 (2017) 582-590. http://dx.doi.org/10.1016/j.molstruc.2017.01.008

37. B. Haddad, J. Kiefer, H. Brahim, E.H. Belarbi, D. Villemin, S. Bresson, O. Abbas, M. Rahmouni, A. Paolone, O. Palumbo, Effects of $\mathrm{C}(2)$ methylation on thermal behavior and interionic interactions in imidazolium-based ionic liquids with highly symmetric anions, Applied Sciences, 8(7) (2018) 1043. https://doi.org/10.3390/app8071043

38. B. Haddad, A. Paolone, D. Villemin, M. Taqiyeddine, E.H. Belarbi, S. Bresson, M. Rahmouni, N.R. Dhumal, H.J. Kim,J. Kieferh, Synthesis, conductivity, and vibrational spectroscopy of tetraphenylphosphonium bis (trifluoromethanesulfonyl) imide, Journal of Molecular Structure, 1146 (2017) 203-212. https://doi.org/10.1016/j.molstruc.2017.05.138

39. B. Haddad, A. Paolone, D. Villemin, J.F. Lohier, M. Drai, S. Bresson, O. Abbas, E.H. Belarbi, para-Xylyl bis-1-methylimidazolium bis (trifluoromethanesulfonyl) imide: Synthesis, crystal structure, thermal stability, vibrational studies, Journal of Molecular Liquids 260 (2018) 391402. https://doi.org/10.1016/j.molliq.2018.03.113

40. Y. Chaker, M. Debdab, E.H. Belarbi, H., Ilikti, B Haddad, T. Moumene, A. Wadouachi, A.N.V. Nhien, H.B. Abassi, O. Abbas, S. Bresson, The influence of chloride and hydrogen sulfate anions in two polymerised ionic liquids based on the poly (1-(hydroxyethyl)-3vinylimidazolium cation, synthesis, thermal and vibrational studies, European Polymer Journal 108 (2018) 138-149. https://doi.org/10.1016/j.eurpolymj.2018.08.032

41. B. Haddad, S.A. Brandan, M.A. Assenine, A. Paolone, D. Villemin, S. Bresson, Bidentate cation-anion coordination in the ionic liquid 1-ethyl-3-methylimidazolium hexafluorophosphate supported by vibrational spectra and NBO, AIM and SQMFF $\begin{array}{llllll}\text { calculations, Journal of Molecular Structure } 1212 & \text { (2020) } & 128104 .\end{array}$ https://doi.org/10.1016/j.molstruc.2020.128104

42. S.K. Panja, B. Haddad, M. Debdab, J. Kiefer, Y. Chaker, S. Bresson, A. Paolone, Cluster formation through hydrogen bond bridges across chloride anions in a hydroxyl-functionalized ionic liquid, ChemPhysChem 20(7) (2019) 936-940. https://doi.org//10.1002/cphc.201801206

43. B. Haddad, A. Paolone, M. Drai, M. Boumediene, D. Villemin, E.H. Belarbi, M. Rahmouni, S. Bresson, O. Abbas, Para-xylyl linked bis-imidazolium ionic liquids: A study of the conformers of the cation and of the anion-cation hydrogen bonding, Journal of Molecular Structure 1175 (2019) 175-184. https://doi.org/10.1016/j.molstruc.2018.07.096

44. M.A. Villetti, F.I. Ziembowicz, C.R.R Bender, C.P. Frizzo, M.A.P. Martins, T.D. de Souza, C.L. Kloster, I.T. Garcia, Thermodynamic insights into the binding of mono-and dicationic imidazolium surfactant ionic liquids with methylcellulose in the diluted regime, The Journal of Physical Chemistry B 121(35) (2017) 8385-8398. https://doi.org/10.1021/acs.jpcb.7b03525 
45. B. Haddad, D. Villemin, E.H. Belarbi, N. Bar, M. Rahmouni, New dicationic piperidinium hexafluorophosphate ILs, synthesis, characterization and dielectric measurements, Arabian Journal of Chemistry 7(5) (2014) 781-787. https://doi.org/10.1016/j.arabjc.2011.01.002

46. B. Haddad, T. Moumene, D. Villemin, J.F. Lohier, E.H. Belarbi, Bis-methyl imidazolium methylidene bis (trifluoromethanesulfonyl) imide, crystal structure, thermal and dielectric studies, Bulletin of Materials Science 39(3) (2016). 797-801. https://doi.org/10.1007/s12034016-1193-z

47. K. Kaewtatip, C. Chiarathanakrit, S.A. Riyajan, The effects of egg shell and shrimp shell on the properties of baked starch foam, Powder Technology 335 (2018) 354-359. https://doi.org/10.1016/j.powtec.2018.05.030 
Scheme 1. General procedure for the synthesis of IL and DIL, (MW: Microwave).
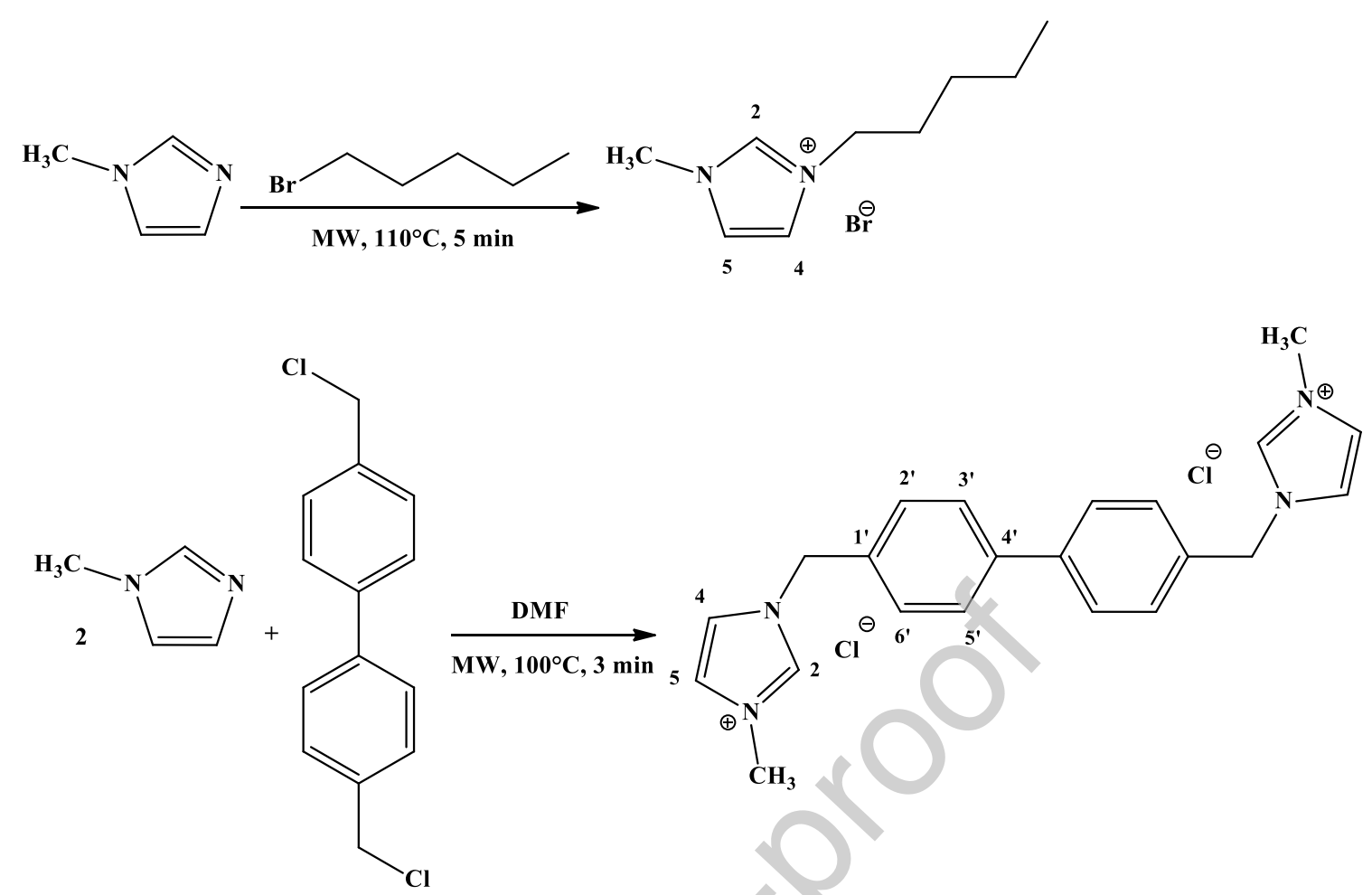
Figure 1. XRD patterns of egg shell (ES) and egg shell with membrane (ESM) before and after modification by monocationic ionic liquid (IL) and dicationic ionic liquid (DIL)
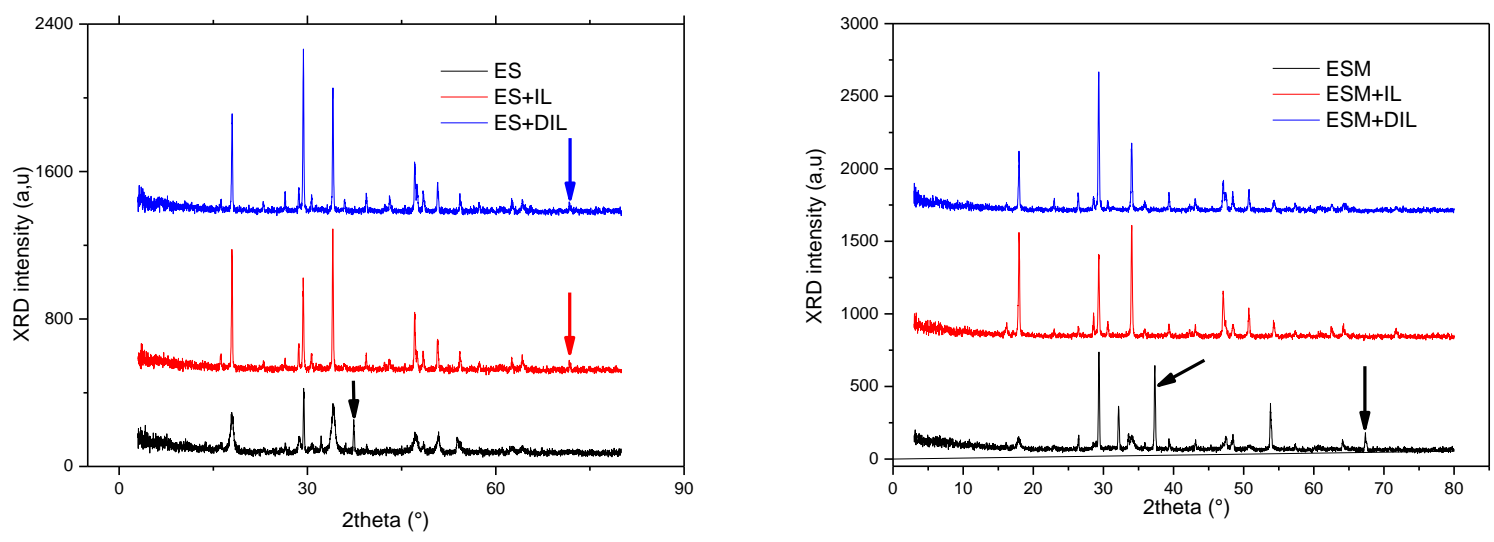
Figure 2. IR spectra of monocationic ionic liquid (IL) and dicationic ionic liquid (DIL)

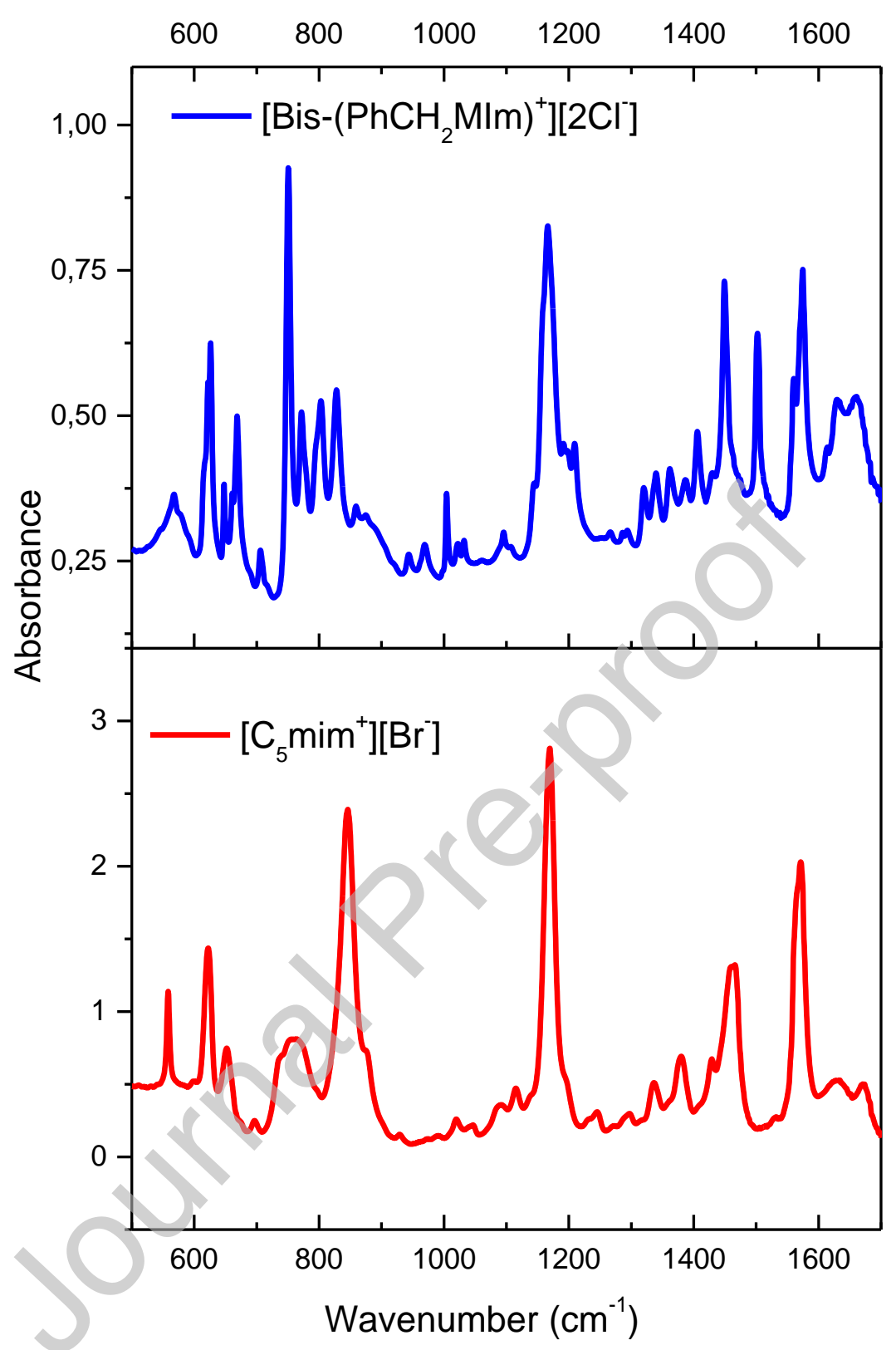


Figure 3. IR spectra of egg shell (ES) and egg shell with membrane (ESM)
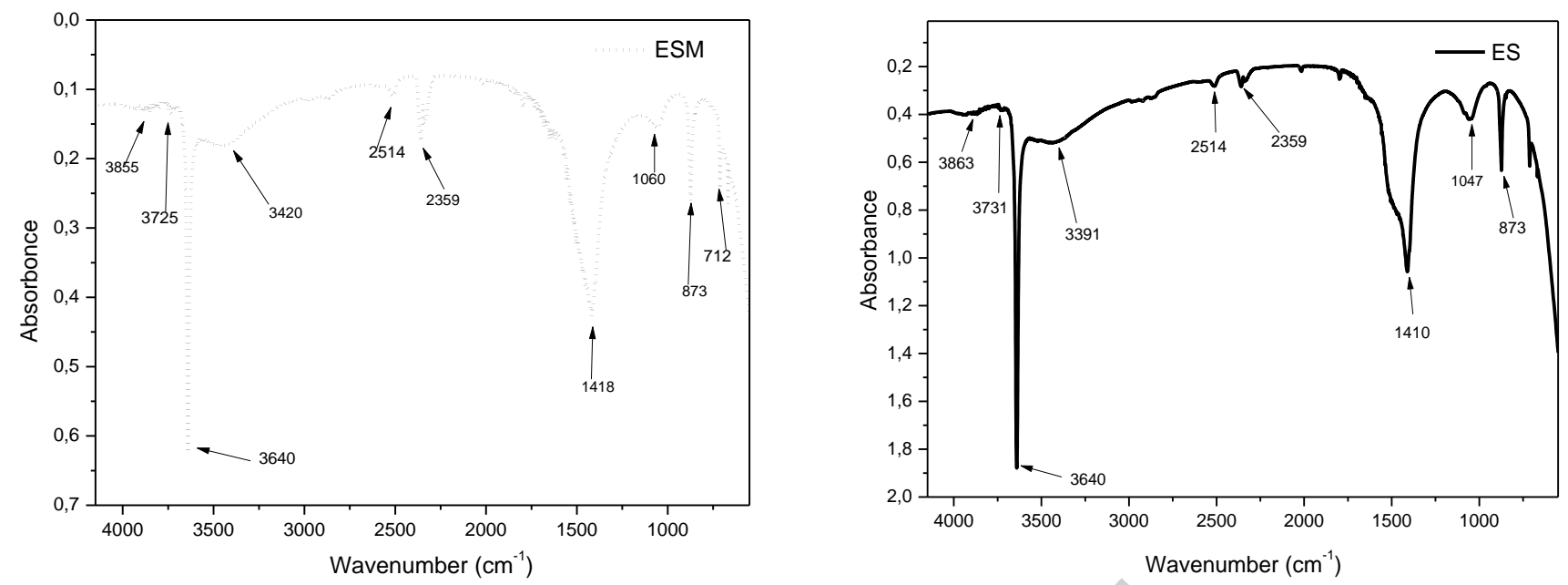
Figure 4: IR spectra of egg shell (ES) and egg shell with membrane (ESM) after modification by monocationic ionic liquid (IL) and dicationic ionic liquid (DIL)
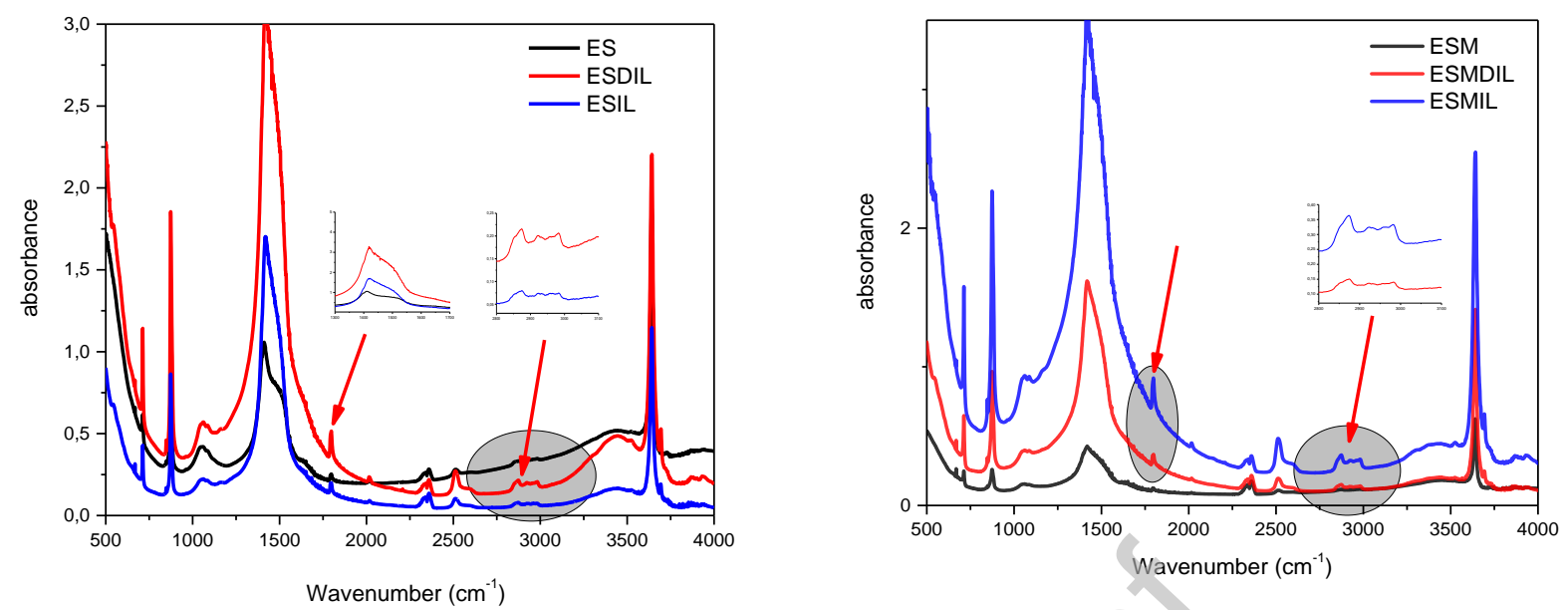
Figure 5. Thermal analysis curves of monocationic ionic liquid (IL) and dicationic ionic
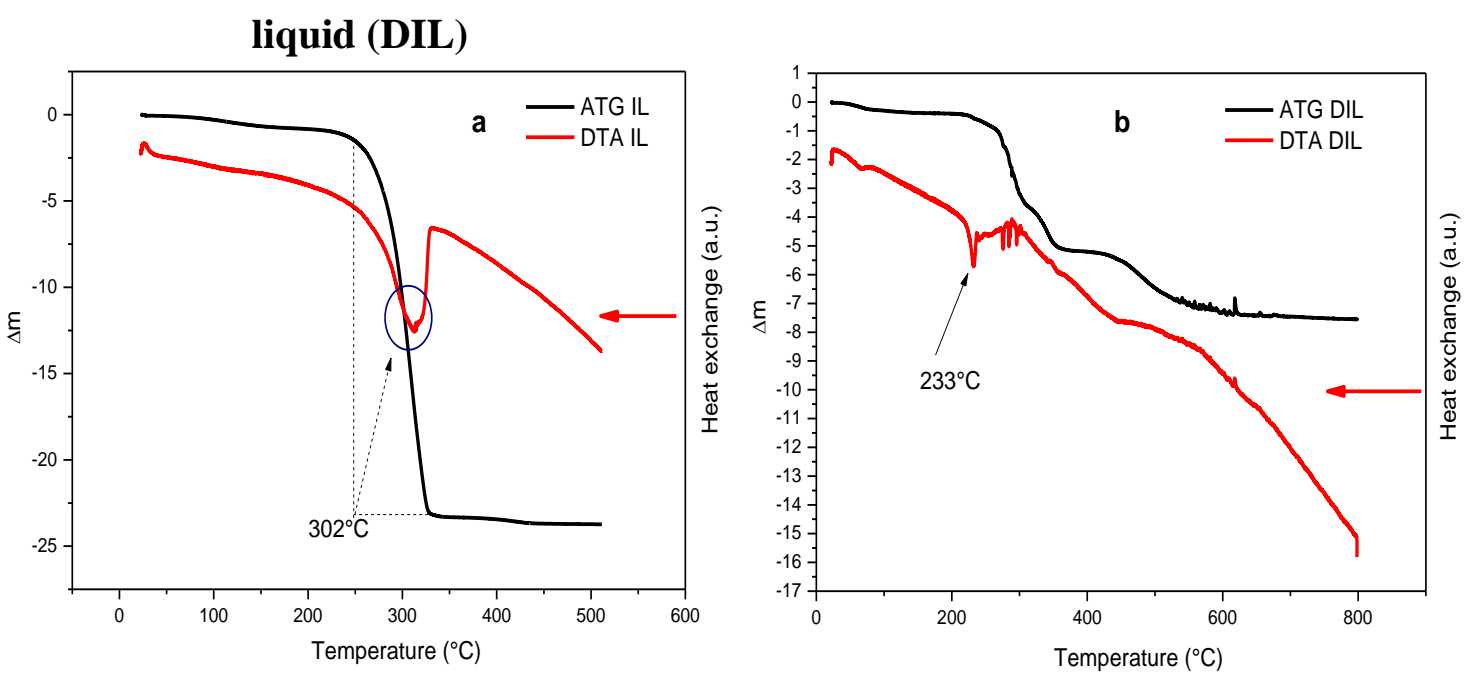
Figure 6: TGA curves of egg shell (ES) and egg shell with membrane (ESM) before and after modification by monocationic ionic liquid (IL) and dicationic ionic liquid (DIL)
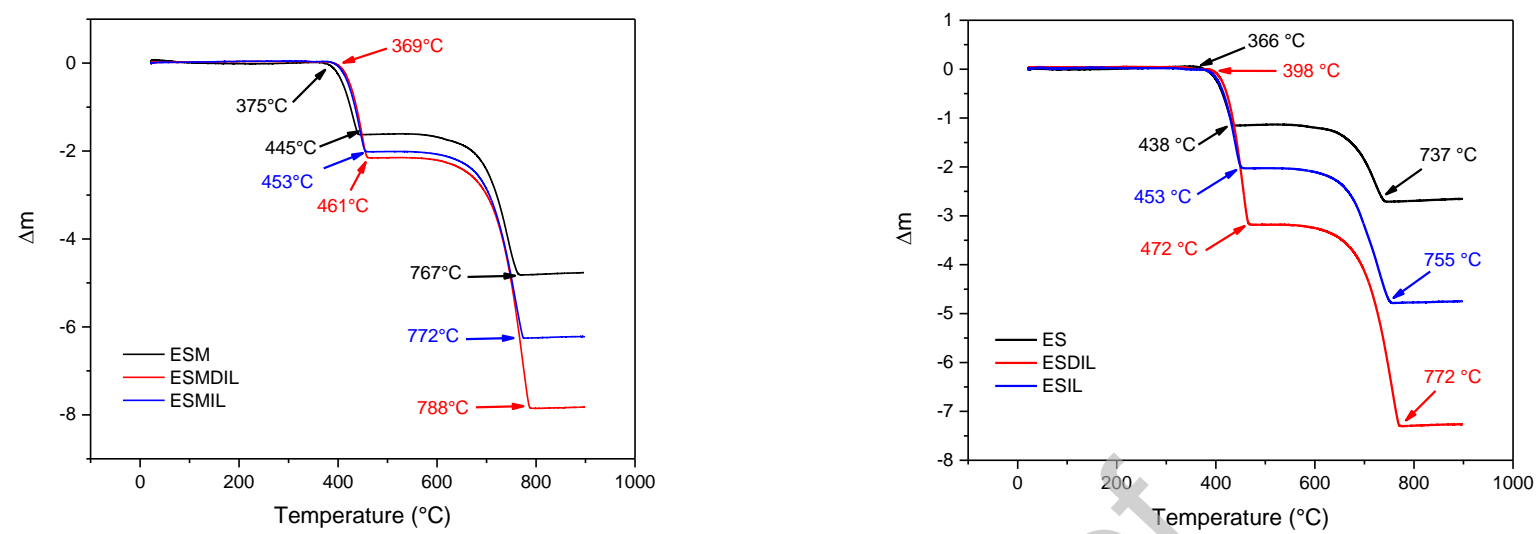
Figure 7: $\quad$ DTA curves of egg shell (ES) and egg shell with membrane (ESM) before and after modification by monocationic ionic liquid (IL) and dicationic ionic liquid (DIL)
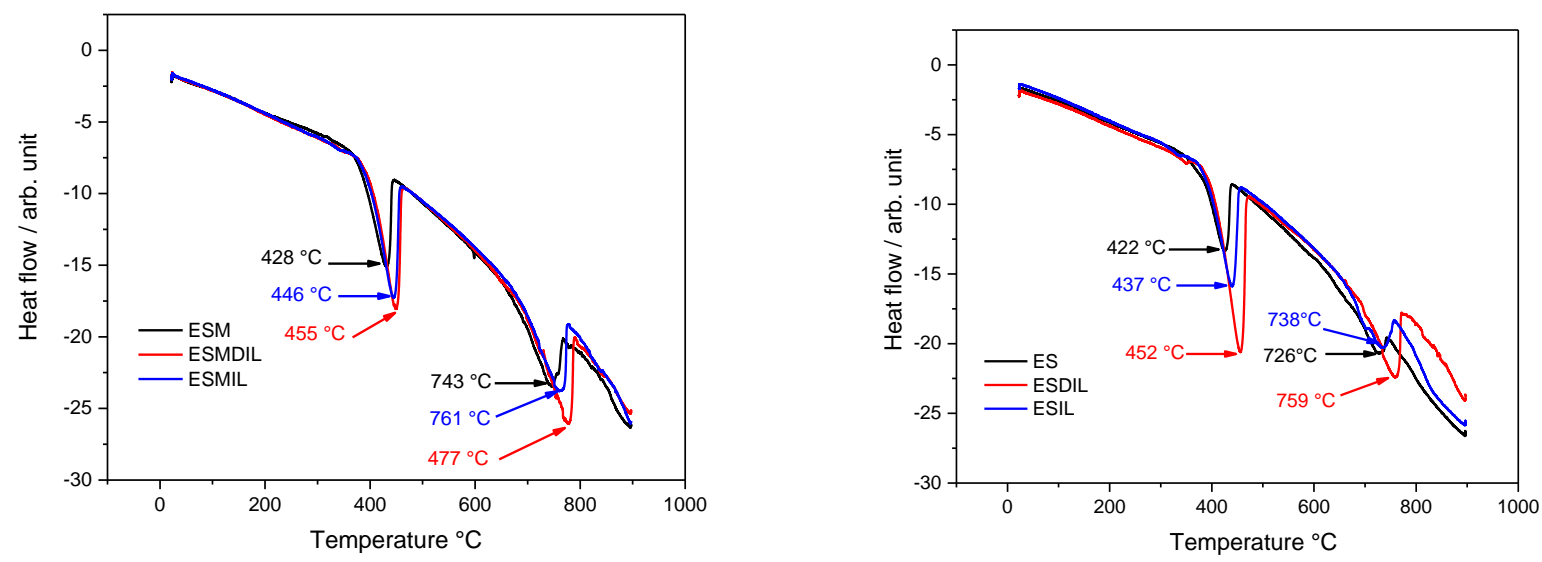
Table - 1. NMR Spectroscopic Data of Monocationic and Dicationic Ionic Liquids

\begin{tabular}{|c|c|}
\hline Type of Ionic Liquid & Details of ${ }^{1} \mathbf{H}-\mathbf{N M R}$ and ${ }^{13} \mathbf{C}$-NMR Spectrum \\
\hline \multirow{2}{*}{$\begin{array}{l}\text { Monocationic } \\
{\left[\mathbf{C}_{5} \mathbf{m i m}^{+}\right]\left[\mathbf{B r}^{-}\right]}\end{array}$} & $\begin{array}{l}{ }^{1} \mathbf{H}-\mathbf{N M R}\left(\mathbf{C D C l}_{3}\right) \boldsymbol{\delta}_{\mathbf{H}}(\mathbf{p p m}) \\
10.08\left(1 \mathrm{H}, \mathrm{s}, \mathrm{N}^{+} \mathrm{CH} N\right), 7.42\left(1 \mathrm{H}, \mathrm{s}, \mathrm{N}^{+} \mathrm{C} \underline{\mathbf{H}}\right), 7.26(1 \mathrm{H}, \mathrm{s}, \\
\left.\mathrm{NC} \underline{\mathbf{H}}^{\prime}\right), 4.28-4.24\left(2 \mathrm{H}, \mathrm{t}, \mathrm{J}=2.6 \mathrm{~Hz}, \mathrm{~N}^{+} \underline{\mathrm{CH}}_{2}\right), 4.02(3 \mathrm{H}, \mathrm{s}, \\
\left.\mathrm{NC}_{3}\right), 1.86-183\left(2 \mathrm{H}, \mathrm{m}, \mathrm{J}=6.4 \mathrm{~Hz}, \mathrm{NCH}_{2} \mathrm{C} \underline{\mathbf{H}}_{2}\right), 1.37-1.31 \\
\left(4 \mathrm{H}, \mathrm{m}, \mathrm{J}=2.8 \mathrm{~Hz}, \mathrm{NCH}_{2} \mathrm{CH}_{2} \mathrm{CH}_{2} \underline{\mathrm{CH}}_{2}\right), 0.81(3 \mathrm{H}, \mathrm{t}, \mathrm{J}=6.8 \mathrm{~Hz}, \\
\left.\mathrm{N}^{+}\left(\mathrm{CH}_{2}\right)_{4} \underline{\mathrm{C}}_{3}\right)\end{array}$ \\
\hline & 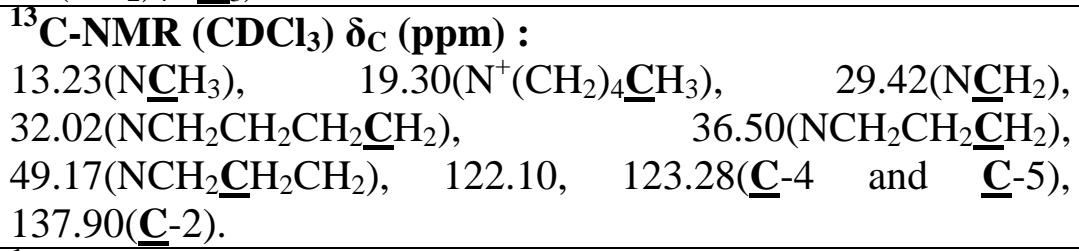 \\
\hline \multirow{2}{*}{$\begin{array}{c}\text { Dicationic Ionic Liquid } \\
\left.\left[\text { Bis-( }^{-} \mathbf{P h C H}_{2} \mathbf{M I m}\right)^{+}\right]\left[\mathbf{2 C l}^{-}\right]\end{array}$} & 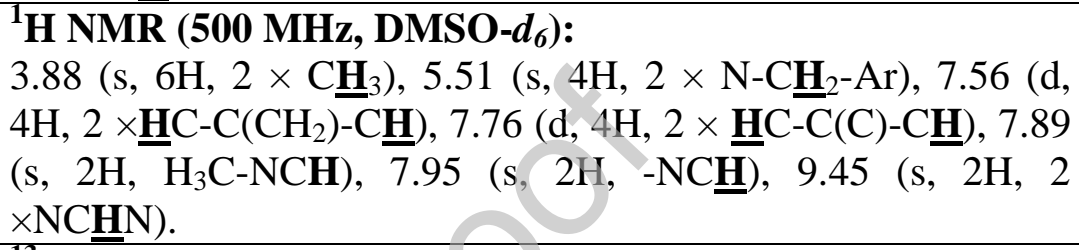 \\
\hline & 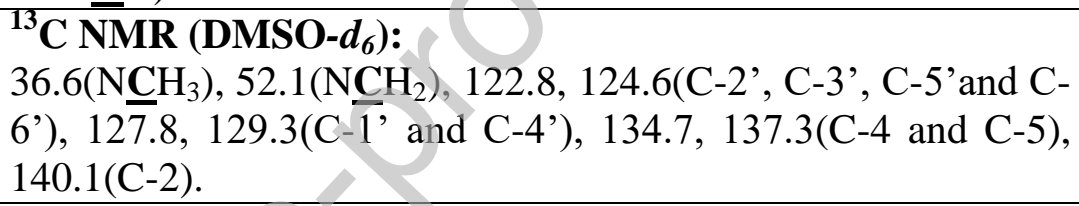 \\
\hline
\end{tabular}

